\title{
Avaliação da correlação entre escore fecal e matéria seca das fezes de bezerros neonatos com diarreia por Cryptosporidium parvum
}

Luana Coeli Araújo Ferreira", Filipe Lucas de Melo Mendonça, Elias Jorge Facury Filho, Antônio Último de Carvalho, Markus Vinicius Vieira de Araújo, Rafael José da Silva, Layanne Duarte Ferreira, João Paulo Andrade, Joana Ribeiro da Glória, Rodrigo Melo Meneses

Departamento de Clínica e Cirurgia Veterinárias, Escola de Veterinária, Universidade Federal de Minas Gerais (UFMG), Belo Horizonte, MG, Brasil

*Autor correspondente

e-mail: lulucoeli@gmail.com

\section{Resumo}

O Cryptosporidium spp. é um protozoário comumente associado à diarreia neonatal em bezerros, principalmente no período entre cinco a quinze dias de vida. Este enteropatógeno parasita o ápice dos enterócitos e as criptas intestinais, e a lesão das células resulta em diarreia má absortiva, que associa-se a uma diarreia hipersecretória resultante do processo inflamatório desenvovido. 0 desequilíbrio hidroeletrolítico somado à má absorção intestinal resulta em desidratação, hipoglicemia e acidose metabólica, que podem levar a óbito. 0 objetivo foi acompanhar a perda de líquidos pelos bezerros durante a Criptosporidiose, por meio da análise da correlação entre o teor de matéria seca fecal e a caracterização da consistência das fezes. Foram utilizados 32 bezerros inoculados oralmente com um milhão de oocistos de Cryptosporidium parvum, no terceiro dia de vida. A Criptosporidiose foi confirmada pela técnica de centrífugo-sedimentação das fezes em formol/éter e coloração do esfregaço pela técnica de Ziehl Neelsen modificada. Os bezerros foram avaliados quanto ao início, duração, intensidade e término da diarreia de acordo com o escore fecal, que caracteriza como diarreicas as fezes com escore superior ou igual a dois: zero (fezes normais), um (fezes pastosas), dois (fezes aquosas), três (diarreia profusa com fezes liquefeitas). Foram coletadas 23 amostras fecais por bezerro ao longo do primeiro mês de vida de cada animal, exceto daqueles que vieram a óbito antes do trigésimo dia de vida, totalizando 687 amostras. Cada amostra foi pré-seca em estufa a $55^{\circ} \mathrm{C}$, por cinco dias, moída em moinho especializado com peneira de um milímetro e, posteriormente, seca em estufa a $105^{\circ} \mathrm{C}$, durante quatro horas. 0 teor de matéria seca foi calculado por meio da diferença de peso da amostra antes e após o processo de secagem, e o percentual encontrado foi relacionado ao escore de fezes, que caracterizou as respectivas amostras. A média dos escores fecais zero, um, dois e três foram 17,366\%, $12,407 \%, 8,321 \%$ e $5,165 \%$, respectivamente. Os resultados foram estatisticamente avaliados por meio do 
teste de correlação de Spearman e o coeficiente encontrado $(-0,83)$ confirma que à medida que o escore de fezes aumenta, o teor de matéria seca fecal diminui. Ao longo do primeiro mês de vida dos bezerros, o teor de matéria seca das fezes diminui com o início da diarreia, continua decrescendo durante a patência do quadro e se reestabelece com o fim da enfermidade até sua completa normalização. Esse período de diminuição da matéria seca caracteriza a intensa perda de água pelo animal com diarreia, reforçando a importância do monitoramento dessa enfermidade e da reposição hidroeletrolítica. Os resultados obtidos mostram que o escore proposto tem alta correlação com a matéria seca das fezes e, portanto, pode ser utilizado com segurança em avaliações clínicas e experimentais. 